\title{
Corporate Failure: Causes and Remedies
}

\author{
David O. Mbat ${ }^{1} \&$ Eyo I. Eyo ${ }^{2}$ \\ ${ }^{1}$ Professor of Banking and Finance, Faculty of Management Sciences, University of Calabar, Calabar, Nigeria \\ ${ }^{2}$ Lecturer of Banking and Finance, Faculty of Management Sciences, University of Calabar, Calabar, Nigeria \\ Correspondence: Eyo I. Eyo, Department of Banking and Finance, Faculty of Management Sciences, University of \\ Calabar, Calabar, Nigeria. Tel: 234-803-350-0121.E-mail:eyoakamba@gmail.com
}

Received: September 23, 2013

Accepted: October 18, 2013

Online Published: October 31, 2013

doi:10.5430/bmr.v2n4p19

URL: http://dx.doi.org/10.5430/bmr.v2n4p19

\begin{abstract}
Corporate failure is of very important interest to economic, financial and corporate managers. Corporate failure could be seen in terms of the inability of a corporate organization to conform itself with its strategic path of growth and development to attain its economic and financial objectives as well as legal obligations. This paper has considered the factors that can cause corporate failure and its attendant inability to attain these objectives. Corporate organizations have been advised to establish research and development departments to continuously monitor their performance and to introduce effective ways by which they could satisfy their consumers and service their operating environments to effectively continue as going concerns.
\end{abstract}

Keywords: Bankruptcy, Firms, Failure, Effects, Intervention

\section{Introduction}

The topic of this paper which is corporate failure has been a subject of intensive research and discussion by economists, bankers, creditors, equity shareholders, accountants, marketing and management experts, etc. It has also, in several occasions, attracted the attention of both local and international commentators. The reason is that any corporate failure can destabilize the economic system in various ways such as increasing unemployment by throwing workers into the labour market, increasing the level of poverty, depriving people, especially creditors of their legitimate earnings as well as intensifying the crime rate and reduction in the volume of tax earnings.

The disastrous and social effects of corporate failure makes it imperative for shareholders, creditors, government, etc to continually monitor the operations of a corporate entity in order to avoid possible failure. The main focus of this paper is to consider the causes and remedies of corporate failure. As it has been stated in the opening paragraph, various groups of professionals have deep interest in the operating performance of a corporate body. It may not be possible to blend the interests of these various groups, but through the harmonious relationship between management and employees, corporate bodies and their environments, something could be done to stabilize corporate bodies and prevent them from failure (Dietz and Gillespie, 2012).

The paper is classified into five main sections, the first section deals with the conceptualization of corporate failure within the framework of this paper, the second examines the nature of corporate failure, the third discusses the causes and effects of corporate failure, the fourth section proposes the various remedies that should be applied to minimize corporate failure while the fifth section is the conclusion.

\section{Conceptual issues}

It is important to clearly define the concept of corporate entity in order to induce appropriate understanding within the framework of this paper. A corporate entity could be found within the public sector or private sector. In the first instance, the understanding is that, it has a legal status of its own and could be simply known as a legal person. As a legal person, it could sue and be sued in the court of law in the course of pursuing its legitimate corporate activity or interest.

The interest of this paper is to identify the causes and effects of corporate failure especially in Nigeria and to suggest ways by which the incidence of corporate failure could be minimized in order to stabilize economic and financial operations. Thus, the contents will be valuable not only as an addition to existing literature on the subject area but, also, a pointer to salient areas otherwise neglected by financial and, or corporate managers. The paper is however not quantitative because of the inadequacy of reliable data on the subject area. 
As an entity or organization or a corporation, it must exhibit a clearly defined organizational structure within which functional roles could be distinctly differentiated as well as provide the direction and scope of authority. These form the effective basis of organizational or corporate management. Secondly, the corporate entity must be one in which ownership is separated from management. Thus, management and the board of directors perform separate functions which must be properly coordinated and complimentary to achieve common corporate objectives and goals. There are two basic reasons for separating public from private corporate entities. The first is that there is a natural predominance of private enterprises in the economic sphere and subordinate role of public initiation in any situation other than manifest national emergency (Shonefield, 1970). The second reason is that public corporate bodies are affected by direct or indirect intervention of public authorities which may distort the processes of effective management. Thus, government controlled enterprises cannot be effectively compared with private enterprises. As observed by Meggison, Nash and VanRandenborgh (1994), privatized firms, on the average, experience relative increases in profits, operational efficiency and workforce or employment levels better than when they were controlled by public authorities. Thus, the focus of this paper will be on private corporate bodies in which management and Board of Directors can easily play a complimentary role in formulating and implementing remedial measures to offset corporate failure.

The nature of corporate failure

Every corporate entity is expected, ab initio, to formulate corporate strategy as well as put in practice the various decision patterns that will:

1) Define the strategic nature of business that it intends to undertake as well as the type of economic and human resources it intends to organize based on trustworthiness properly embedded in ethical culture of the environment aimed at developing the attitude of the employee to give their best in terms of productivity (Dietz and Gillespie, 2012);

2) Produce the major policy strands as well as plan to achieve the objectives and goals (Mbat, 2001);

3) Shape and reveal its objectives and goals especially, through research and development efforts (Preston, 1975).

Any corporate strategy is intended to meet the demand of the market place in order to generate profit. However, many corporate bodies fail as soon as they are established because of inappropriately formulated strategy or lack of it. This produces corporate failure which could be traced to managerial inefficiency and ineffectiveness.

A corporate body can equally fail because of its inability to appropriately apply financial resources available to it. This can create a liquidity problem which could be traced to different aspects of corporate operations. A situation where corporate managers cannot make effective resource mobilization and allocation decisions, the end result would be low returns and subsequently inability to pay dividends to shareholders at the end of an operating period.

Very often than not, failed corporate entities can still be in existence for quite some time without the knowledge of shareholders. This could be traced to different forms of window dressing effected by management and the board with the collusion of external auditors (McQueen, 1987). External auditors are well placed in a position to forewarn management on financial, accounting and management problems inherent in a firm. If they fail to do this, they have failed in their duties as external auditors. They are interested in keeping the job in the company which ultimately will fail and they lose the job anyway. A case in point is the United States Company known as Enron (International Swaps and Derivatives Association [ISDA], 2002). No matter the type of window dressing that is done to the accounts of the company, outright failure that will be known to everybody is imminent. This is a situation where a company is technically insolvent. There are many cases of technically insolvent firms in Nigeria especially, in Akwa Ibom and Cross River states.

Three types of corporate failure could easily be identified namely:

1) A corporate body with low or negative returns (Berryman, 1982).

2) A corporate body that is technically insolvent (Bedelan, 1984).

3) A corporate body that is bankrupt (Berryman, 1982) and (Baird and Rasmussen, 2002).

A corporate entity that continuously exhibits low or negative returns is bound to fail sooner or later because there is no opportunity for expansion. A firm is technically insolvent when it is unable to meet its liabilities as at when due. The assets of the firm may be higher than its liabilities but because of its critical liquidity situation, it is unable to meet its liabilities. A firm that is bankrupt exhibits a situation where total assets is less than total liabilities, thus the ratio between assets and liabilities is less than one. However, technical insolvency and bankruptcy are always similarly treated in the courts of law. 


\section{Causes and Effect of Corporate Failure}

Corporate failure could be caused by number of factors, such as;

1) Managerial inefficiency and ineffectiveness

2) Socio-cultural factors.

3) Economic instability.

4) Public policy.

\subsection{Managerial inefficiency and ineffectiveness:}

This constitutes the most pronounced source of corporate failure. The first is lack of a well articulated corporate strategic plan. The derivatives of this could consist of over expansion, ineffective sales force, high production cost, inappropriate costing strategies, low productivity, poor financial management strategy, poor risk assessment strategy (Bhattacharjee, Higson, Holly and Kattuman, 2002).

\subsection{Over expansion:}

A company that undertakes over expansion is likely to immobilize short-term funds thereby creating an avenue for corporate failure. Corporate expansion should therefore be made to follow strictly corporate strategic plan (Mbat, 2001).

\subsection{Ineffective sales force:}

The end result of production is to sell the product. If the sales force is not properly trained and developed, the company may find it difficult to sell its product especially if the product is sold in a highly differentiated competitive market. This situation will create cash flow problem and by implication, solvency problem (Gilman, 2001).

\subsection{High production costs:}

This is a situation where the production cost of a firm makes its product not to compete favourably with other differentiated products in the market. This could be due to over employment of human and material resources or technical inefficiency in the production process (Bowen, Morara and Mureithi, 2009).

\subsection{Poor financial management:}

A firm whose financial manager is unable to take effective financial management decisions is bound to experience acute liquidity problem. Such decisions include investment, financing and dividend policy decisions (Richard and Steward, 1986) and (Preston and Post, 1975).

\subsection{Risk assessment strategy:}

The risk associated with an investment decision should be properly evaluated. The reason is that investments in assets constitute the most important source of corporate earnings. Thus, if risk assessment is not properly done, corporate income would be impaired (Mbat, 2001).

\subsection{Inappropriate commercial policy:}

Policies affecting sales especially credit sales should be carefully evaluated since such could lead to debt build up and by implication liquidity crises (Alo, 2003).

\subsection{Absence of manpower training and development policy:}

A firm that does not have manpower training and development policy cannot make use of well trained and specialized staff that can help in the achievement of corporate objectives. An evaluation of strategic business units will show average poor performance of staff which occupies critical positions in the organization (Bedelan, 1987).

Above factors constitute management inefficiency and ineffectiveness. They are very important for observation as an organization moves along the line of achieving its objectives and goals. Other factors which can cause corporate failure are:

\subsection{Capital inadequacy:}

A firm that is undercapitalized is bound to fail sooner or latter. The reason is that the firm will not have enough capital to buy the relevant fixed assets, invest in enough income generating assets or enough working capital. Very often than not, such firms experience underutilization of capacity. This still is an aspect of management ineffectiveness. Moreover, capital structure could create a problem which ultimately ends up in corporate failure. For 
example, if the capital structure is highly geared instead of being lowly geared it may create income sharing problems (Caballero and Krishnamurthy, 1999).

\subsection{Socio cultural factors:}

A firm that produces products which are not absorbed by the immediate environment will have tough times selling its products. It will force the firm to look for distant markets which will lead to higher marketing costs and inability to sell its products (Hopenhayn, 1992).

\subsection{Income instability:}

Environmental economic instability can lead to corporate failure. The reason being that any downturn in the economy can create some form of financial distress due to a firm's inability to sell its products (Caballero and Hammour, 1994)

\subsection{Public policy:}

Public policy is a very important external source of corporate failure. When government policy is against the interest of a firm within the short-term period, the firm could go bankrupt. For example, if government places a ban on importation of a firm's input, production will be impossible when the existing stock inputs are exhausted (Robson, 1996).

The possible effects of corporate failure include:

1) Increase in the level of unemployment.

2) Decreasing standard of living.

3) Underutilization of resources.

4) Increase in crime level.

5) Instability of the banking system due to inability to pay back borrowed funds.

6) Instability of the financial markets where short to medium and long-term funds were sourced and corporate failure makes it impossible to meet such obligations

\section{Remedial measures of minimizing corporate failure}

The identified causes of corporate failure could be used to minimize its incidence. The most effective measure of averting corporate failure is the institution of a very effective management. The responsibility of management would be to look at all areas of operations to see how efficiency could be induced. Such areas include:

1) Staff training and development. This is important in the sense that the employees are expected to lead all areas of job performance and the essence of training is to make them improve on job performance.

2) Enhancement of productivity and business process re-engineering. These consist three important areas namely: improvement in productivity, application of appropriate financial structure, increasing the level of competitive advantage in the market place.

3) Effective management of the product and product market.

4) Compliance with the provisions of the Companies and Allied Matters Act (CAMA) 2004.

The product market is where the firm generates its income, attains its strategic objectives and goals as well as achieves long-term success. Management should continuously monitor the following factors to see how they could be brought under control. These are:

1) Sales price variance.

2) Sales volume variance.

3) Sales mix variance.

4) Sales quantity variance.

5) Market size variance.

6) Market share variance.

For example, it is widely known that the sales price variance is the actual selling price $\mathrm{P}_{0}$ minus the budgeted selling price- $b_{0}$ multiplied by the actual number of units sold $n_{0}$.

That is, $\left(\mathrm{P}_{0}-\mathrm{b}_{0}\right) \mathrm{x} \mathrm{n}_{0}=$ sales price variance. 
The sales volume variance is simply determined as the number of units sold $\mathrm{n}_{0}$ minus number of units budgeted for sales $n_{b}$ multiplied by the budgeted contribution margin per unit of the product sold $C_{b}$.

That is, $\left(\mathrm{n}_{0}-\mathrm{n}_{\mathrm{b}}\right) \times \mathrm{C}_{\mathrm{b}}$

Another important way of averting corporate failure is through the strategic performance measurement. This is an accounting system used by top management to evaluate well known stragtegic business units (SBUs). These remedial measures cannot be effectively carried out if a corporate body does not institute an effective and functioning research and development department ( $\&$ \& $)$. The essence of this unit is to continuously monitor internal and external factors and make appropriate recommendations as to what should be done to keep a firm on the path of sanity. The absence of R\&D department would in addition give rise to poor product conceptualization which would be at variance with what the consumers demand. The authors are currently working on a paper that will help to identify empirical factors that predict corporate failure.

\section{Conclusion}

A lot of factors, internal and external, to the firm could be responsible for corporate failure. Corporate failure exerts negative impact on both local and international economic environments. The incidence of corporate failure in Nigeria is not well researched into except as it concerns the banking industry. However, the country has experienced a high incidence of micro, small and medium business failure which has exerted disastrous negative impact on the local environment. However, researches concerning this category of business have not been widely published.

An effective way of averting corporate failure is to consider the relative influence of management, board of directors, employees, external auditors, regulatory bodies, government etc on the operating performance of a firm and see how they can contribute positively to maintain a firm as a going concern. Corporate bodies that are quoted on the Nigerian stock exchange are effectively supervise by both the Securities and Exchange Commission (SEC) and the Nigerian Stock Exchange (NSE) to avert and minimize corporate failure.

It is recommended that Supervisory Agencies (SAs) should be established in each state of Nigeria to effectively supervise the operations of the micro, small and medium enterprises to adequately comply with the provisions of the Companies and Allied Matters Act (CAMA) 2004, as amended. This is to ensure that the operations of these companies are not at variance with the provisions of the Act.

\section{References}

Alo, O. (2003). Issues in corporate governance. An FITC Publication.

Baird, D. G. and Rasmussen, R. K. (2002). The end of bankruptcy. Stanford Law Review 55. 751 - 789. http://dx.doi.org/10.2307/1229669

Bedelan, A. G. (1987). Management. Japan: Dryden Press Ltd.

Berryman, J. E. (1982). Small business bankruptcy and failure - A survey of the literature in small business research, W. C. Dunlop and W. J. Sheehan ed.

Bhattacharjee, A., Higson, C., Holly, S. and Kattuman, P. (2002). Macroeconomic instability and business exit: Determinants of failures and acquisitions of large UK firms. Journal of Economic Dynamics and Control 1(2). $18-33$.

Bowen, M., Morara, M. and Mureithi, S. (2009). Management of small business challenges among small and micro enterprises in Nairobi - Kenya. KCA Journal of Business Management 2(1). 16 - 31. http://dx.doi.org/10.4314/kjbm.v2i1.44408

Caballero, R. and Hammour, M. (1994). The cleansing effects of recessions. American Economic Review 84. 1350-1365.

Caballero, R. and Krishnamurthy, A. (1999). Emerging markets crisis - An assets markets perspective. IMF Working Paper 99/129. Washington: The International Monetary Fund.

Dietz, G. and Gillespie, N. (2012). The recovery of trust: Case studies of organizational failures and trust repair. Institute of Business Ethics (IBE) Occasional Paper 5. Retrieved from http://www.ibe.org.op_trustcasestudies.pdf

Dun and Bradstreet (2012). Investors' relations. www.dnb.com

Gilman, L. J. (2001). Principles of managerial finance ( $9^{\text {th }}$ Edition). India: Addison Wesley Longman. 
Hopenhayn, H. A. (1992). Entry, exit and firm dynamics in long run equilibrium. Econometrica 60. 1127-1150. http://dx.doi.org/10.2307/2951541

International Swaps and Derivatives Association (2002). Enron: Corporate failure, market success. ISDA $17^{\text {th }}$ Annual General Meeting, Berlin, $17^{\text {th }}$ April. Retrieved from www.isda.org.

Mbat, D. O. (2001). Financial management. Uyo: DOMES Associate.

Megginson, W. R., Nash, R. and VanRandenborgh, M. (1994). The financial and operating performance of newly privatised firms: An international empirical analysis. Journal of Finance 49. 403-452. http://dx.doi.org/10.1111/j.1540-6261.1994.tb05147.x

McQueen, J. (1987). New insolvency law take effect. Accountant Record. 31-33.

Preston, L. E. and Post, J. E. (1975). Private management \& public policy. London: Prentice Hall International.

Richard, B. and Steward, M. (1986). Principles of corporate finance. Singapore: McGraw Hill Book Company.

Robson, M. T. (1996). Macroeconomic factors in birth and death of UK firms: Evidence from quarterly VAT registrations. The Manchester School 64. 170-188. http://dx.doi.org/10.1111/j.1467-9957.1996.tb00479.x

Shonefield, A. (1970). Modern capitalism. New York: OUP. 